\title{
Relationships between Innovation Capabilities, Business Performance, Marketing Performance and Financial Performance: A Literature Review
}

\author{
Syed Shah Alam (Corresponding author) \\ Faculty of Economics and Business, Universiti Kebangsaan Malaysia, Bangi, Selangor 43600, \\ Malaysia \\ E-mail: shahalam@ukm.my
}

Vijayesvaran Arumugam

Infrastructure University Kuala Lumpur, Jalan Ikram-Uniten, 43000 Kajang, Selangor 43009, Malaysia

E-mail: vijay@kliuc.edu.my

Noor Gani Mohd Nor

Faculty of Economics and Management, Universiti Kebangsaan Malaysia, UKM Bangi, Selangor, Malaysia

\section{Pushpa A/P Kaliappan}

Infrastructure University Kuala Lumpur, Jalan Ikram-Uniten, 43000 Kajang, Selangor 43009, Malaysia

E-mail: pushpa_a@yahoo.com

Lee Sze Fang

Infrastructure University Kuala Lumpur, Jalan Ikram-Uniten, 43000 Kajang, Selangor 43009, Malaysia

E-mail: szefang_5036@yahoo.com

Received: January 7, 2013 Accepted: March 13, 2013 Published: March 21, 2013

doi:10.5296/bmh.v1i1.3415 URL: http://dx.doi.org/10.5296/bmh.v1i1.3415 


\begin{abstract}
Innovation is one of the basic component use by the corporate as a stretegy to improve productive manufacturing processes, to be able to compete in the market and to establish good reputation to gain positive status in customers's perception. This paper has been designed to review the existing literature available on firm innovation capabilities and its influence on performance (i.e. business, marketing and financial performance). After reviewing the existing literature on firm innovation capabilities, the researchers have found that firm innovation capabilities have greater influence on business performance, marketing performance and ultimately influence on financial performance. Theoretical framework has been develop on the basis of the reviewed literiture, showing the relationship between firm innovation capabilities and performance.
\end{abstract}

Keywords: innovation capabilities, business performance, marketing performance 


\section{Introduction}

The process of equipping in new, improved capabilities or increased utility has been defined by Drucker (1985) as innovation. An innovation is related to products, processes, marketing and organization. Different types of innovation has been described by Schumpeter (1934), which are new products, new methods of production, new sources of supply, the exploitation of new market, and new ways to organize business. Innovation capability is one of the attractive areas that need to be studied by the researchers to define, categorize and investigate its performance impacts. In order to achieve sustainable competitive advantage, the firms were provided the strategic orientation to overcome the problems they were facing. (e.g. Drucker, 1985; Hitt et al., 2001; Kuratko et al., 2005).

According to McAdam and Keogh (2004), firms believe that innovations were the important factor to obtain sustainable competitive advantage. Geroski (2005) analyzed the effects of innovations and patents to various organization performance measures in terms of accounting profitability, stock market rates of return and corporate growth. Result obtained by Geroski (2005) showed that it is relatively small direct effect of innovations on firm performance and the benefits from innovations are likely indirect. Companies have noticed the importance of innovation through the increasing competition in global markets such as value added of existing products and services. Innovation is one of the basic component use by the corporate as a stretegy to improve productive manufacturing processes, to be able to compete in the market and to establish good reputation to gain positive status in customers's perception.

The aim of this paper is to blend the representative existing literature on the relationship between innovation capabilities with business, marketing and financial performances based on methodical literature review. In doing so, this study attempt to find out on how antecedents are related and can contribute to increase of business, marketing and financial performances to help firm perform better.

\section{Methods}

We have analytically searched the following 19 main journals of Innovation Capabilities journals; among it is: The Impact Of A Responsive And Proactive Market Orientation On Innovation And Business Performance, Innovative Capabilities Operations Priorities and Corporate Performance In Manufacturing Firms, Dynamic Capabilities A Review and Research Agenda, Technological Innovation Capabilities and Firm Performance, Customer Relationship Management and Innovation Capability An Empirical Study, A Research In Relating Entrepreneurship, Marketing Capability, Innovative Capability and Sustained Competitive Advantage, Organizational Innovative Capabilities Malaysian Firm, Innovation Capability and Export Performance An Empirical Study Of Textile Businesses In Thailand and Empirical Research On The Effects Of Organizational Innovation On Organizational Performances.

In addition, we have also searched 9 primary Innovation Capabilities; among it is: The Relationship Between Environmental and Business Performance An Empirical Study Conducted In The Dutch Food and Beverages Industry, Strategic Marketing and Business 


\section{Al Macrothink}

Business and Management Horizons

ISSN 2326-0297

2013, Vol. 1, No. 1

Performance A Study In Three European Engineering Countries, Benchmarking Marketing Capabilities For Sustainable Competitive Advantage, Beware The Silver Metric Marketing Performance Measurement Has To Be Multidimensional, Innovation Sources Capabilities and Competitiveness Evidence From Hong Kong Firm and The Effects Of Innovation Capability On New Product The Evidence Of Zhejiang Province. We have also checked the references sections of the selected articles to identify and have a better understanding in this area.

\subsection{A Classification of Relationship between Innovation Capabilities and Business, Financial and Marketing Performances}

A total of 28 empirical studies are analyzed in this study. Of these 19 of them used survey methods. Other research uses questionnaire to address the aspect of innovation capabilities. Our goal is to develop a classification representation factors/elements related to innovation capabilities that has been covered in the existing empirical studies. After examining the 28 empirical studies, we found a total of 15 interconnected factors for which the empirical evidences show significant relationship. These 15 factors that were being identified is product and service innovation, process and marketing innovation, strategic innovation, resources allocation and organizing capabilities, marketing capabilities, financial performances, marketing performances, business performances, sales value, sales growth, gross profit, cost reduction, revenues, market share and finally the fifteen customer retention. All the fifth teen is found to be ordinarily independent and in addition that financial performances are also dependent to marketing performances.

Out of the 28 studies examined not all factors being covered and there is inconsistence in the empirical study results of those that included similar factors. Nonetheless, for the sake of discussion, we integrate these fifth teen factors in a model (Figure 1) in which the expected connection among them are depicted.

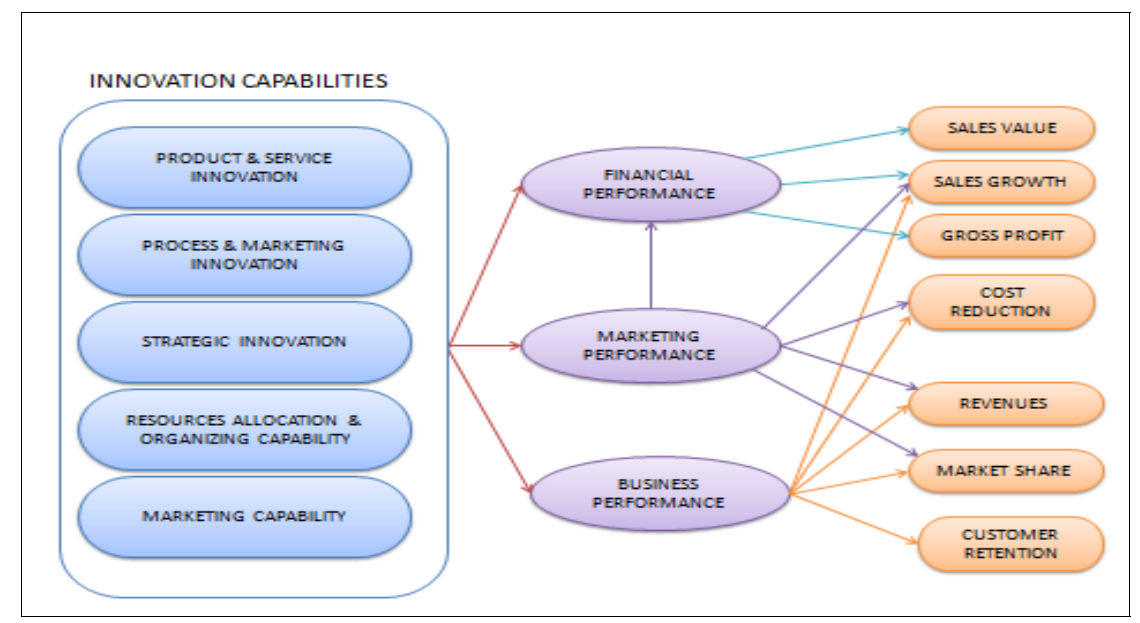

Figure 1. Model of relationship between innovation capability, business, marketing and financial performance 


\subsection{Product \& Service Innovation}

There are 21 journals out of 28 studies evidence which has shows a strong relationship between product innovation and market performance (Narver, 1990). Kotler (1991) mentioned that corporate revenue's return hit more than $50 \%$ on innovation account. The development of technology has contributes to the product and process innovations (OECD, 2005). An introduction of a new or significantly improved good or service is defined as product innovation. (OECD, 2005). Products innovations can be achieved through utilize the new or existing knowledge or technologies. However, various factors such as advance technologies, customer needs change, short product life cycles and global competition increase may cause the product innovation is a difficult process. (OECD, 2005). Communication within the firm, between the firm and its customers and suppliers is an essential step to be successes in product innovation.

According to the study conducted by A.Oke, the success of product / service innovations can be achieved through the improvement of processes (Oke, 2007). In addition, marketing and product innovation are positively related. Both have effect on each other. For example, when the level of the marketing innovation is high, the level of the product / service innovation is also high. Firms will attempt to develop products in a shorter time or response quickly to the new product introduce by their competitors in order to overcome the competitive threat (OECD, 2005). This leads to competitive advantage increase. Firm financial performance can be improved through innovation such as the ability to response quickly to market forces, develop and launch new products with a lower lead times (OECD, 2005).

\subsection{Process \&Marketing Innovation}

We have found 20 articles related to process innovation. The implementation of a new or significantly improved production or delivery method such as changes in techniques, equipment or software is defined as process innovation. (Fagerberg et al., 2004). Process innovation take place when the unit cost of production decreased, quality increased or new product introduced (OECD Oslo Manual, 2005). Fagerberg et al. (2004) emphasized that cost-cutting nature due to the process innovation will have a positive effect on the growth of income and employment.

A significant change in product design, packaging, placement and promotion or pricing is defined as a marketing innovation (OECD, 2005). In order to increase the firm's sales, marketing innovation will be implemented through fulfill the customer needs better, opening up new markets, or re-position a firm's product on the market. Marketing innovations are strongly related to the four P's of marketing, which are pricing strategies, product package design properties, product placement and promotion activities (Baldwin and Johnson, 1996).

Clark (1999) offered expanded measurements of marketing performance, which include the financial aspect that is, profitability, salability, cash flow, and non-financial aspect that is, customer satisfaction, customer loyalty and brand equity. The "Innovation Strategy" has a significantly positive influence upon organizational marketing performance. Bonoma and 
Clark (1988) said that a financial performance is highly tied together with cash flow, market share, sales growth rate and profitability.

\subsection{Strategic Innovation}

There are 10 journals talks about strategic innovation that creates value for firm which is also known as new competitive strategies. Strategic innovation is directly related to basic business activities within an organization (Liao et al, 2007).

Strategic innovation is also known as the factor of identifying external opportunities which is also match with external opportunities and internal capabilities this is an important element that is needed to deliver innovative product and new market exploration (Liao et al, 2007).

\subsection{Resources Allocation \& Organizing Capability}

During this research, 14 articles were reviewed which is related to expand of technological in relates to mobilize with regards to firms ability, financial and human resource in innovation process. Product innovation is said to be dependable on the leverage of organizational resources and capabilities which is owned by internal functional units or in combination with research institutions, universities, customer and suppliers. Theory suggest that difficult to imitate and rare in market provide a firm to be competitive enough by having distinctive resources or capabilities which are valuable. Element of innovation requires combination of these resources to be essential. Nelson and Pack (1999) also said that the complementary assets that provide the foundation of dynamic capabilities and competitiveness are the factor to integrate build and reconfigure the resources.

Innovation supporting activities are measured by how well a firm manages its capital investment and human in resources allocation capability. There are firms in Hong Kong exhibit a better resource allocation capability and can allocate limited resources more effectively in transforming ideas into commercial products which lead to competitive products. Empirical studies show that financial and human resources in small and medium enterprise are crucial for innovation Nelson and Pack (1999).

\subsection{Marketing Capability}

16 articles were reviewed on marketing capabilities. It was pointed that function of marketing requires complete market knowledge, create and provide valuable and excellent product and service towards their target customer, Weerawardena (2003). To have a better and longer competitive advantage and profit, than company need to highly respond to the need of market and predict the market situation proactively. According to Weerawardena (2003), marketing capabilities is an indispensible factor that is based in innovative capabilities of a company which can generate growth and profit via distinctive innovation capabilities.

According to Liu et al. (2009), it was said that tangible and intangible resources and capabilities are important in marketing capabilities for marketing operation, including brand, sales, channel and service to provide various marketing service. 
2.7 Financial Performance- relationship with Sales Value, Growth \& Gross Profit

Financial performances refer to factors of sales value, sales growth and gross profit or profitability. We have reviewed 12 journals on financial performances which suggested the market performance positively impacts the financial performances. Whereas business performance can be divided into two groups which is one financial and second non-financial. Financial performance refers to the extent to which the organization performs in relative sales value, sales growth and gross profit / profitability, (Li.L, 2000).

According to the study carried out by Hakan Kitapci, Bulent Aydin and Vural Celik, the financial performance was represented by the sales value, and general profit of the organization. (Kitapci, Aydin, \& Celik, 2011). As marketing growth and sales growth directly contribute to the profits of the organization through increase in price premiums and sales revenues, by decreasing marginal unit costs thus leading to significant overall profits (Wei \& Wang, 2005).

According to E.T.G.Wang and H.L.Wei, firm's sales will be affected by product innovation (Wei \& Wang, 2005). According to the prior study done by William and Michael, sales growth is the most significant growth variable affecting financial performance in the actual industries examined (William \& Michael, 1995).

2.8 Marketing Performance -relationship with Sales Growth, Cost Reduction, Revenues \& Market Share

According to the prior study's result, innovation capability is positively related to market performance. Market innovation is the most significant factor for market performance (AMA 2005). Market performance will be affected by the customer behaviors, which can be measured using unit sales and sales revenue. Thus, the financial performance outcome in terms of revenue, cash flow, and profitability can be determined by the sales performance of the firm. (Day and Fahey, 1988; Kaplan and Norton, 1993). The US American Marketing Association White Paper (AMA 2005) identified Incremental sales revenue, Ratio of cost to revenue, Cost per sale generated, Changes of financial values of sales generated, Cost of new customer and Cost of old customer retention as the ROI measurement (AMA 2005).

Recently, a methodology for projecting a firm's ROI in service quality has been introduced by the "return on quality" model (Rust et al., 1995). Research has shown the possibility of trade-offs between service quality improvement that increase revenue and reduce costs (Anderson, Fornell, and Rust 1997). The financial risk also need to be considered in the approaches to evaluate the financial return (Davis 2002), as is common in corporate finance.

2.9 Business Performance -relationship with Sales Growth, Cost Reduction, Revenues, Market Share \& Customer Retention

There were 9 articles shows strong relationship on business performances. To survive and prosper, a company must be aware of changes in consumer taste to satisfy existing customers and secure new ones, (Ambler et al. 2002). Satisfying consumer requirements, means it is the central focus of an organization's activities, (Ambler et al. 2002). 
Business performance is mainly drives by an important factor which is innovation as per reviewed by Desh-pande and Farley, 2004; Fagerberg, 2005; Davila et al., 2006; Antončič et al., 2007; Bastič, 2007) and is crucial for competitiveness (e.g. Werawardena, 2003; Bastič, 2004). There was empirical study which confirms a positive relationship between new-product performance and business performance (Langerak et al., 2004; Ledwith and O'Dwyer, 2008). Customer loyalty, market share and sales volume is positively impacted by the effectiveness by new-product development process and the ability to successfully launch new products. Administrative, product and process innovation are related to business performance in positive way.

At the time market success or market position is achieved, it will resulted in business performance as an outcome (Day \& Wensley, 1988) and essentially will change over time (Rust et al., 2004). Both levels of current and future levels of performance measure should retain business performances. As per mentioned by (Varadarajan \& Jayachandran, 1999), a broad and well-balanced performance conceptualized financial and non financial methods which will assist marketers to fully reconize the performance consequences of their startegies. Business performance term is used as a general performance construct to detain both market and fiancial aspects of presentation, (Rust et al., 2004).

\section{Conclusions and Recommendation}

Based on the literature review on firm innovation capabilities have shown that to get a greater impact on the firm's overall performance, the organisations have to implement effective innovation culture in the organisation. The organisations which implement such innovative culture, remains ahead of their competitors because this innovations ultimately affects other variables such as business performance, marketing performance and finally overall financial performance. This will help organisations to grow in a bigger scale.

\section{References}

Adler, P., \& Shenhar, A. (1990). Adapting your technological base: The organizational challenge. Sloan Management Review, 32(1), 25-37.

AMA. (2005). Marketing Accountability Study: White Paper. Chicago: American Marketing Association.

Ambler,T. (2000). Marketing and the Bottom Line. London: Financial Times/Prentice Hall.

Anderson, E. W., ClaesFornell \& Roland, T. R. (1997). Customer Satisfaction, Productivity, and Profitability: Differences Between Goods and Services. Marketing Science, 16(2), 129-145. http://dx.doi.org/10.1287/mksc.16.2.129

Andriopoulos, C., \& MantoGotsi. (2000). Benchmarking Brand Management in the Creative Industry. Benchmarking: An International Journal, 7(5), 360-72.

Baldwin, J. R., \& Johnson, J. (1996). Business strategies in more- and less-innovative firms in Canada. Research Policy, 25, 785-804. http://dx.doi.org/10.1016/0048-7333(95)00875-6

Barney, J. B. (1991). Firm Resources and Sustained Competitive Advantage. Journal of 
Management 17(1), 99-120. http://dx.doi.org/10.1016/0048-7333(95)00875-6

Berry, M. A., \& Taggart, J. (1994). Managing Technology and Innovation: A Review. R\&D Management, 24, 341-353. http://dx.doi.org/10.1111/j.1467-9310.1994.tb00889.x

Bertrand, M., \& Mullainathan, S. (2001). Do People Mean What They Say? Implications for Subjective Survey Data. American Economic Review, 91(2), 67-72. http://dx.doi.org/10.1257/aer.91.2.67

Bettis, R. A., \&Hitt, M. A. (1995). The new competitive landscape. Strategic Management.

Bonoma, T. V, \& Clark, B. C. (1988). Marketing Performance Assessment. Boston: Harvard Business School Press.

Brockett, P. L., Golden, L., Sarin, S., \& Gerberman, J. H. (2001). The Identification of Target Firms and Functional Areas for Strategic Benchmarking. The Engineering Economist, 46(4), 274-99. http://dx.doi.org/10.1080/00137910108967578

Brownlie, D. (2000). Benchmarking Your Marketing Process. Long Range Planning, 32(1), 88-95. http://dx.doi.org/10.1016/S0024-6301(98)00129-0

Burgelman, R. M. (2004). Strategic Management of Technology and Innovation, 8-12.

Buzzell, R., \& Gale, B. (1987). The PIMS principles: Linking strategy to performance. Free Press.

Camp, R. C. (1989). Benchmarking: The Search for Best Practices That Lead to Superior Performance. Milwaukee, WI: ASQC Quality Press.

Capon, N. et al. (1992). Profiles of Product Innovators Among Large United-States Manufacturers. Management $\quad$ Science, $\quad 38(2), \quad$ 157-169. http://dx.doi.org/10.1287/mnsc.38.2.157

Clark, B. H. (1999). Marketing performance measures: History and interrelationships. J. Mark. Manage, 15(8), 711-733. http://dx.doi.org/10.1362/026725799784772594

Czarnitzki, D., \& Spielkamp, A. (2003). Business services in Germany: Bridges for innovation. The Service Industries Journal, 23(2), 1-30. http://dx.doi.org/10.1080/02642060412331300862

D'Este, P. (2002). The distinctive patterns of capabilities accumulation and inter-firm heterogeneity: the case of the Spanish pharmaceutical industry. Industrial and Corporate Change, 11(4), 847-874. http://dx.doi.org/10.1080/02642060412331300862

Damanpour, F., \& Evan, W. M. (1984). Organisational innovation and performance: the problem of "organisational lag". Administrative Science Quarterly, 29(3), 392-409. http://dx.doi.org/10.2307/2393031

Daneels, E. (2002). The dynamics of product innovation and firm competences. Strategic Management Journal, 23, 1095-1121. http://dx.doi.org/10.1002/smj.275 
Davis, C. R. (2002). Calculated Risk: A Framework for Evaluating Product Development. Sloan Management Review, 43(4), 71-77.

Day, G. S., \& Fahey, L. (1988). Valuing market strategies. J Mark, 52, 45-57. http://dx.doi.org/10.2307/1251449

Day, G. S., \&Wensley, R. (1988). Assessing advantage: A framework for diagnosing competitive superiority. Journal of Marketing, 52(2), 1-20. http://dx.doi.org/10.2307/1251261

Dhalla, N. K. (1976). Assessing the Long-Term Value of Advertising. Harvard Business Review, 54(1), 87-95.

Dougherty, D. (1992). Interpretative barriers to successful product innovation in large firms. Organization Science, 3, 179-202. http://dx.doi.org/10.1287/orsc.3.2.179

Drucker, P. F. (1985). Innovation and Entrepreneurship. Butterworth-Heinemann, Oxford.

Fagerberg, J., Mowery, D. C., \& Nelson, R. R. (2004). The Oxford Handbook of Innovation. Oxford University Press.

Fleming, L. (2001). Recombinant uncertainty in technological search. Management Science, 47(1), 117-132. http://dx.doi.org/10.1287/mnsc.47.1.117.10671

Fornell, C. (1992). A National Customer Satisfaction Barometer: The Swedish Experience. Journal of Marketing, 56(January), 1-21.

Freeman, C., \& Soete, L. (1997). The Economics of Industrial Innovation (3rd ed.). London: Pinter.

Geroski, P. (1995). Innovation and competitive advantage. Working Paper No. 159, OECD, Paris.

Gopalakrishnan, S., \& Damanpour, F. (1997). A review of innovation research in economics, sociology and technology management. Omega, 25(1), 147-66. http://dx.doi.org/10.1016/S0305-0483(96)00043-6

Gourville, J. T. (2006). Eager Sellers \& Stony Buyers. Harvard Business Review, 84(6), 98106.

Griliches, Z., \& Mairesse, J. (1984). Productivity and R\&D at the Firm Level. In Griliches, Z. (Ed.), $\quad R \& D, \quad$ Patents and Productivity. Chicago. http://dx.doi.org/10.7208/chicago/9780226308920.001.0001

Guan, J. (2002). Comparison Study of Industrial Innovation between China and Some European Countries. Production and Inventory Management Journal, 43(3).

Guan, J., \& Ma, N. (2003). Innovative capability and export performance of Chinese firms. Technovation, 23, 737-747. http://dx.doi.org/10.1016/S0166-4972(02)00013-5

Gurisatti, P., Soli, V., \& Tattara, G. (1997). Patterns of diffusion of new technologies in small 
metal-working firms: the case of an Italian region. Industrial and Corporate Change, 6, 275-312. http://dx.doi.org/10.1093/icc/6.2.275

Hagedoorn, J., \& Cloodt, M. (2003). Measuring innovative performance: is there an advantage in using multiple indicators? Research Policy, 32, 1365-1379. http://dx.doi.org/10.1016/S0048-7333(02)00137-3

Han, J. K., Kim, N., \& Srivastava, R. K. (1998). Market orientation and organisational performance: is innovation the missing link? Journal of Marketing, 62(4), 30-45. http://dx.doi.org/10.2307/1252285

Henderson, R., \& Cockburn, I. (1994). Measuring competence: Exploring firm effects in pharmaceutical research. Strategic Management Journal, 15(special issue), 63-84. http://dx.doi.org/10.1002/smj.4250150906

Hitt, M. A., Ireland, R. D., Camp, S. M., \& Sexton, D. L. (2001). Guest editors' introduction to the special issue strategic entrepreneurship: entrepreneurial strategies for wealth creation. Strategic Management Journal, 22, 479-491. http://dx.doi.org/10.1002/smj.196

Hooley, G. J., Greenley, G., Cadogan, J. W., \& Fahy, J. (2005). The performance impact of marketing resources. Journal of Business Research, 58(1), 18-27. http://dx.doi.org/10.1016/S0148-2963(03)00109-7

Hooley, G., \& Greenley, G. (2005). The resource underpinnings of competitive positions. $\begin{array}{llrr}\text { Journal of Strategic } \quad \text { Marketing, } & \text { 13(2), }\end{array}$ http://dx.doi.org/10.1080/09652540500082968

Hooley, G., Greenley, G., Fahy, J., \& Cadogan, J. (2001). Market-focused resources, competitive positioning and firm performance. Journal of Marketing Management, 17(5-6), 503-520. http://dx.doi.org/10.1362/026725701323366908

Hult, G. (2003). The role of entrepreneurship in building cultural competitiveness in different organizational types. Journal of Management, 401-426.

Hult, G. T., Ketchen, Jr., D. J. (2001). Does market orientation matter? A test of the relationship between positional advantage and performance. Strategic Management Journal, 22, 899-906. http://dx.doi.org/10.1002/smj.197

Jacobson, R., \& David, A. A. (1985). Is Market Share All It's Cracked Up to Be? Journal of Marketing, 49(October), 11-22. http://dx.doi.org/10.2307/1251428

Jen Lin, R., Huei Chen, R., \& Shun Chiu, K. (2010). Customer relationship management and innovation capability: an empirical study. Industrial Management \& Data Systems, 111-133. http://dx.doi.org/10.1108/02635571011008434

Johne, A., \& Davies, R. (2000). Innovation in medium-sized insurance companies: how marketing adds value. International Journal of Bank Marketing, 18(1), 6-14. http://dx.doi.org/10.1108/02652320010315316

Kirpalani, V. H., \& Stanley, S. S. (1973). Financial Dimensions of Marketing Management. 
Journal of Marketing, 37(July), 40-49. http://dx.doi.org/10.2307/1249945

Kitapci, H., Aydin, B., \& Celik, V. (2011). The effects of organizational learning capacity andinnovativeness on financial performance: An empirical Study. African Journal of Business Management, 6(6), 2332-2341.

Kotler, P. (1991). Marketing Management: Analysis, Planning, Implementation, \& Control (7th ed.). Prentice Hall, Englewood Cliffs, New York.

Kuratko, D. F., \& Hodgetts, R. M. (1998). Entrepreneurship: A Contemporary Approach. Dryden Press, Fort Worth.

Kuratko, D. F., Ireland, R. D., Covin, J. G., \& Hornsby, J. S. (2005). A model of middle-level managers' entrepreneurial behaviour. Entrepreneurship Theory and Practice, 29(6), 699-716.

Lall, S. (1992). Technological Capabilities and Industrialization. World Development, 20(2), 165-168. http://dx.doi.org/10.1016/0305-750X(92)90097-F

Langerak, F., Hultink, E. J., \& Robben, H. S. J. (2004). The impact of market orientation, product advantage, and launch proficiency on new product performance and organizational performance. Journal of Product Innovation Management, 21(2), 79-94. http://dx.doi.org/10.1111/j.0737-6782.2004.00059.x

Lawless, M. J., \& Fisher, R. J. (1990). Sources of Durable Competitive Advantages in New Products. Journal of Product Innovation Management, 7(1), 35-43. http://dx.doi.org/10.1016/0737-6782(90)90030-I

Lawless, M., \& Anderson, P. (n.d.). Generational technological change: effects of innovation and local rivalry on performance. Academy of Management Journal, 39(5), 1185-1217.

Ledwith, A. \& O'Dwyer, M. (2008). Product launch, product advantage and market orientation in SMEs. Journal of Small Business and Enterprise Development, 15(1), 96-110. http://dx.doi.org/10.1108/14626000810850865

Lee, R. P., Johnson, J. L., \& Grewal, R. (2008). Understanding the antecedents of collateral learning in new product alliances. International Journal of Research in Marketing, 25(3), 192- 200. http://dx.doi.org/10.1016/j.ijresmar.2008.03.002

Li, L. (2000). An analysis of sources of competitiveness and performance of Chinese manufacturers. International Journal of Operations \& Production Management, 299-315. http://dx.doi.org/10.1108/01443570010294307

Li, Y., Liu, Y., \& Ren, F. (2007). Product innovation and process innovation in SOEs: Evidence from the Chinese transition. Journal of Technology Transfer, 32, 63-85. http://dx.doi.org/10.1007/s10961-006-9009-8

Liao, S. H., Fei, W. C., \& Chen, C. C. (2007). Knowledge sharing, absorptive capacity, and innovation capability: an empirical study of Taiwan's knowledge-intensive industries. Journal of Information Science, 33(3), 340-59. http://dx.doi.org/10.1177/0165551506070739 
Lin, C. Y., \& Chen, M. Y. (2007). Does innovation lead to performance? An empirical study of SMEs in Taiwan. Management Research News, 30(2), 115-132. http://dx.doi.org/10.1108/01409170710722955

McAdam, R., \& Keogh, K. (2004). Transitioning towards creativity and innovation measurement in SMEs. Creativity and Innovation Management, 13(2), 126-141. http://dx.doi.org/10.1111/j.0963-1690.2004.00300.x

Muller, E., \& Zenker, A. (2001). Business services as actors of knowledge transformation: The role of KIBS in regional and national innovation systems. Research Policy, 30(9), 1501-1516. http://dx.doi.org/10.1016/S0048-7333(01)00164-0

Narver, J. C., \& Slater, S. F. (1990). The Effect of a Market Orientation on Business Profitability. Journal of Marketing, 54, 20-35. http://dx.doi.org/10.2307/1251757

Nelson, R., \& Pack, H. (1999). The Asian Miracle and modern growth theory. The Economic Journal, 109(July), 416-36. http://dx.doi.org/10.1111/1468-0297.00455

Nerkar, A., \& Roberts, P. W. (2004). Technological and Product-Market Experience and the Success of New Product Introductions in the Pharmaceutical Industry. Strategic Management Journal, 25, 779-799. http://dx.doi.org/10.1002/smj.417

Neter, J., Wasserman, W., \& Kutner, M. H. (1990). Applied Linear Statistical Models.

OECD. (2005). Oslo Manual: Proposed Guidelines for Collecting and Interpreting Technological Innovation Data. Paris.

OECD. (2007). Summary report of the study of globalisation and innovation in the business services sector. Paris.

Oke, A. (2007). Innovation types and innovation management practices in service companies. International Journal of Operations and Production Management, 27(6), 564-587. http://dx.doi.org/10.1108/01443570710750268

Peters, B. (2008). Innovation and firm performance: An empirical investigation for German firms.

Quadros, R., Furtado, A., Roberto B., \& Franco, E. (2001). Technological innovation in Brazilian industry: An assessment based on the São Paulo innovation survey. Technological $\begin{array}{lllll}\text { Forecasting } \quad \text { and } & \text { Social 203-219. }\end{array}$ http://dx.doi.org/10.1016/S0040-1625(00)00123-2

Ravichandran, T. (2000). Swiftness and intensity of administrative innovation adoption: An empirical study of TQM in information systems. Decision Sciences, 31(3), 691-724. http://dx.doi.org/10.1111/j.1540-5915.2000.tb00939.x

Richard, C. M. Y., William, L., Esther P. Y. T., \& Antonio, K. W. L. (2010). Technological Innovation Capabilities and Firm Performance. World Academy of Science, Engineering and Technology, 8. 
Romano, N. C. J., \& Fjermestad, J. (2003). Electronic commerce customer relationship management: A research agenda. Information Technology and Management, 4(2-3), 233-258. http://dx.doi.org/10.1023/A:1022906513502

Rust, R. T. (1986). Advertising Media Models: A Practical Guide. Lexington, MA: Lexington Books.

Rust, R. T., Ambler, T., Carpenter, G. S., Kumar, V., \& Srivastava, R. K. (2004). Measuring marketing productivity: Current knowledge and future directions. Journal of Marketing, 68(4), 76-89. http://dx.doi.org/10.1509/jmkg.68.4.76.42721

Rust, R. T., Anthony, J. Z., \& Timothy, L. K. (1995). Return on Quality (ROQ): Making Service Quality Financially Accountable. Journal of Marketing, 59(April), 58-70. http://dx.doi.org/10.2307/1252073

Salmen, S. M., \& Muir, A. (2003). Electronic customer care: The innovative path to e-loyalty. Journal of Financial Services Marketing, 8(2), 133-144. http://dx.doi.org/10.1057/palgrave.fsm.4770113

Schumpeter, J. A. (1934). The Theory of Economic Development.An Inquiry into Profits, Capital, Credit, Interest, and the Business Cycle. Harvard University Press, Cambridge.

Slater, S. F., \& Narver, J. C. (1995). Market orientation and the learning organization. Journal of Marketing, 59(3), 63-74. http://dx.doi.org/10.2307/1252120

Srinivasan, R., Rangaswamy, A., \& Lilien, G. L. (2005). Turning adversity into advantage: Does proactive marketing during a recession pay off? International Journal of Research in Marketing, 22(2), 109-125. http://dx.doi.org/10.1016/j.ijresmar.2004.05.002

Srivastava, R. K., \& David, J. R. (2005). Metrics for Linking Marketing to Financial Performance, Marketing Science Institute Working Paper 05-200.

Srivastava, R. K., Shervani, T. A., \& Fahey, L. (1998). Market-based assets and shareholder value: A framework for analysis. Journal of Marketing, 62(1), 2-18. http://dx.doi.org/10.2307/1251799

Taylor, S. A., \& Hunter, G. L. (2002). The impact of loyalty with e-CRM software and e-services. International Journal of Service Industry Management, 13(5), 452-474. http://dx.doi.org/10.1108/09564230210447931

Varadarajan, P. R., \& Jayachandran, S. (1999). Marketing strategy: An assessment of the state of the field and outlook. Journal of the Academy of Marketing Science, 27(2), 120-143. http://dx.doi.org/10.1177/0092070399272002

Vorhies, D. W., \& Harker, M. (2000). The capabilities and performance advantages of market-driven firms: an empirical investigation. Australian Journal of Management, 25 (2), 145-71. http://dx.doi.org/10.1177/031289620002500203

Walker, R. (2004). Innovation and organizational performance: Evidence and a research agenda. 
Wang, C. (2008). Evaluating firm technological innovation capability under uncertainty.

Weerawardena, J. (2003). Exploring the role of market learning capability in competitive strategy. European Journal of Marketing, 37(3/4), 407-30. http://dx.doi.org/10.1108/03090560310459023

Wei, H., \& Wang, E. (2005). Importance of market orientation, learning orientation, and quality orientation capabilities in TQM: An example from Taiwanese software industry.

William, C. H., \& Michael, E. B. (1995). The impact of sales and income growth on profitability and market value measures in actual and simulated industries..

Wood, P. (2005). A service-informed approach to regional innovation - or adaptation? The Service Industries Journal, 25(4), 429-445. http://dx.doi.org/10.1080/02642060500092063

\section{Copyright Disclaimer}

Copyright reserved by the author(s).

This article is an open-access article distributed under the terms and conditions of the Creative Commons Attribution license (http://creativecommons.org/licenses/by/3.0/). 